\title{
LIMULUS AMOEBOCYTE LYSATE (LAL) TEST - AN ALTERNATIVE METHOD FOR DETECTION OF BACTERIAL ENDOTOXINS
}

\author{
R. BLECHOVÁ ${ }^{1}$, D. PIVODOVÁ ${ }^{2}$ \\ ${ }^{1}$ Department of Pharmacology and Toxicology, Faculty of Pharmacy, \\ University of Veterinary and Pharmaceutical Sciences, Brno, Czech Republic \\ ${ }^{2}$ Institute for State Control of Veterinary Biologicals and Medicaments \\ Brno, Czech Republic \\ Received June 8, 2000 \\ Accepted August 28, 2001
}

Abstract

Blechová R., D. Pivodová: Limulus amoebocyte lysate (LAL) Test-an Alternative Method for Detection of Bacterial Endotoxins. Acta Vet. Brno 2001, 70: 291-296.

The Limulus amebocyte lysate (LAL) test is an alternative method to the rabbit pyrogen test focussed on detection of pyrogenic substaces in sterile parenteral drugs.

The aim of this work is the evaluation and introduction to common day use of LAL test gel-clot method for assay of bacterial endotoxins (the most common pyrogens) in examined product. A total number of 15 samples were tested for bacterial endotoxins to verify the method in our laboratory conditions. In 6 products, the presence of pyrogens was examined using simultaneously the LAL test and the rabbit pyrogen test.

The replacement of the rabbit pyrogen test by the LAL test gel-clot method is possible when the endotoxin limit for the observed drug product is defined, the set maximal endotoxin concentration level in such material is acceptable and standardised test procedures and validation techniques are established.

There are many advantages of LAL test over the rabbit pyrogen test, however, one of the most important aspects of LAL test is that LAL test is in accordance with the latest demand of the European Pharmacopoeia Commission for the replacement of the animal-based tests in favour of alternative methods where possible. The tests carried out have proved that the LAL test could replace the rabbit pyrogen test on condition that the validation parameters are fulfilled.

Endotoxin, LAL test, Limulus polyphemus, lysate, pyrogen, rabbit pyrogen test.

Pyrogens

The word pyrogen, which can be traced to the Greek pyro, meaning burning or fire and gennaó, meaning to make or to create, is now used as an apt description for substance that produce elevated body temperature. Pyrogens are usually bacterial products and remains or decaying products of the bacterial cell walls. Even in minimum dose, these substances induce elevated body temperature when injected into humans and animals. Pyrogens are usually high-molecular-weight substances of polymerous nature, like lipopolysacharids. Pyrogens could be either microbial or non-microbial.

\section{Endotoxins}

Endotoxins are high-molecular-weight complexes associated with the outer membrane of gram-negative bacteria (GNB). They are the most usual cause of the elevated body temperature, induced by contaminated drug products. Their pyrogenic activity is higher than that of other pyrogenic substances. It could be said that the absence of such bacterial endotoxins in a drug implies the absence of pyrogenic components in examined drug in general. Endotoxins are similar to lipopolysacharids, they are heat stable and can survive the sterilisation process.

In their molecular structure, endotoxins contain lipid A which is responsible for the

Address for correspondence:

MVDr. Renata Blechová

Department of Pharmacology and Toxicology,

Faculty of Pharmacy. VFU

Palackého 1-3,612 42 Brno, Czech Republic
Phone: +420 541562727

http://www vfu.cz/acta-vet/actavet.htm 
endotoxic activity of the endotoxins. The free form of lipid A, extracted from endotoxins by acid hydrolysis, has almost the same spectrum of biological activities as the endotoxin itself.

Limulus Amebocyte Lysate Test

In current advanced society, the demand for the quality of drugs in ever increasing. This is followed by the advance in the tests for the purity of human and veterinary drugs. These tests are carried in laboratory conditions sometimes with the use of the biological material - live animals.

However, the current trends prefer the use of such supervision mechanisms, by which the use of live animals and finance demanding procedures could be avoided. The consequence of such trends is the introduction of the new laboratory method - the Limulus amebocyte lysate (LAL) test, used for the detection of pyrogenic endotoxins and as an alternative to the rabbit pyrogen test.

The use of LAL for endotoxin detection was derived from Bang's observation that the infection of Limulus polyphemus, the horseshoe crab, induced by GNB, results in extensive intravascular clotting and death. Later on, Levin and Bang demonstrated that the extracellular coagulation of Limulus hemolymph (blood) was caused by an reaction between endoxin and a coagulative protein in amebocytes, circulating in Limulus hemolymph (Levin and Bang 1964). In a subsequent study, Le vin et al. developed a sensitive assay for endotoxin in human plasma using the material lysed from Limulus amebocytes (Le vin et al. 1970). Young, Levin and Prendergast then isolated, purified and described the LAL coagulative protein and proved that the reaction between lysate and endotoxin is of enzymatic nature (Young et al. 1993).

For definition of the endotoxin concentration, it was necessary to set a referential endotoxin standard, expressed in Endotoxin Units (EU) per ml. A single EU is defined as an equivalent of a specific activity of $0.2 \mathrm{ng} \mathrm{EC}-2$, as defined in international endotoxin referential standard by FDA (Food and Drugs Administration) (Friberg 1987).

Legislative classification of LAL test

In the past, the LAL test was considered to be only an alternative method to the rabbit pyrogen test. In the new edition of the European Pharmacopoeia (Eur. Pharm., $3^{\text {rd }} 1996$ ) and Supplement 2001 the LAL test is already mentioned to be of equal value as the rabbit pyrogen test. Analogously, the LAL test is classified at the same level in other national pharmacopoeias as well, for example The United States Pharmacopoeia XXIV (USP 24, 2000), the British Pharmacopoeia (BP, 1999) and the Czech Pharmacopoeia (ČL 97) and its Supplements.

Official pharmacopoeial method

Bacterial endotoxins - LAL test

Nowadays, the six following methods are described in the current European Pharmacopoeia:

Method A: Gel-clot method: limit test

Method B: Gel-clot method: semi-quantitative test

Method C: Turbidimetric kinetic method

Method D: Chromogenic kinetic method

Method E: Chromogenic end-point method

Method F: Turbidimetric end-point method

The gel-clot technique (Method A and B) allows detecting or quantification of endotoxin and is based on clothing of the lysate in the presence of endotoxins. The concentration of endotoxins required to cause the lysate to clot under standard condition is the labelled lysate sensitivity. 
Kinetic method: Both methods $C$ and D make use of the linear regression of the logarithm of the response on the logarithm of the endotoxin concentration.

End-point method: Method $\mathrm{E}$ and $\mathrm{F}$ are based on the quantitative relationship between the endotoxin concentration and the quantity of chromophore (method E) released at the end of incubation period, respective the turbidity of the reaction mixture (European Pharmacopoeia. 2000).

Maximum endotoxin dose in a parenteral solution which a patient can take into without any side effect is for:

1. intravenous application

2. intravenous application for radiopharmaceuticals

3. intrathecal application

(European Pharmacopoeia 2000)
5.0 EU per kg weight per hour 2.0 EU per kg weight per hour $0.2 \mathrm{EU}$ per kg weight per hour

Maximum endotoxin concentration for one millilitre of a product has to correspond to its maximum dose. The dose for a healthy adult man must not exceed 350 EU. Minimal endotoxin concentration is then set by dividing 350 EU by maximal dose of a correspondent product. Plasma of healthy humans contains about $0.07 \mathrm{EU} / \mathrm{ml}$ (it is 6 $\mathrm{pg} / \mathrm{ml}$ ), this is theoretically about a half of endotoxin blood concentration during a pyrogen reaction (Friberg 1987).

Pyrogens - biological test

The test consists of measuring the rise in body temperature induced in rabbits by the intravenous injection of sterile solution of product to be examined.

The main test is carried out using a group of three rabbits. If necessary, the test is repeated on further groups of three rabbits until the final and total number of twelve tested animals is reached. A rabbit is not to be used in a pyrogen test, if it has been used in a negative pyrogen test in the preceding 72 hours, or if has been used in the 144 preceding hours in a pyrogen test in which the substance under examination failed to pass the test. The same rabbit can be used for $25-30$ pyrogen tests.

Aim

Evaluation of the method for determination of bacterial endotoxins by LAL test - gel-clot method - limit test as a routine test for the performance of bacterial endotoxin test.

\section{Materials and Methods}

Samples analyses were carried out by the gel-clot method - limit test. This method is described in European Pharmacopoeia (European Pharmacopoeia 2000)

Principle

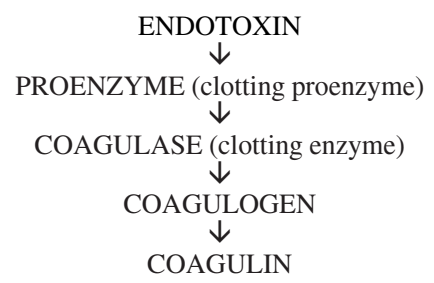

GNB endotoxin catalyses the activation of proenzyme in the LA lysate. The initial rate of activation is determined by the concentration of present endotoxin. The activated enzyme [coagulase] hydrolyzes specific bond within a clotting protein [coagulogen] also present in LAL. Turbidity precipitation and gel forms can occur after 
mixing bacterial endotoxin with LA lysate, however, only gel formation is considered as end-point (Young et al.1993).

Commercial test kit was used for analyses: Pyrogent Plus 64 test kit and Pyrogent plus 200 test kit produced by BioWhittaker company, USA with sensitivity of LA lysate 0.125 EU per ml. These kits contain $10 \mathrm{ng}$ control standard endotoxin (CSE) E. coli 055:B5 and LA lysate of labeled sensitivity. Both the products are distributed in lyophilized form. Both CSE and LAL were reconstituted by LAL Reagent Water (contain of endotoxin $<0.005$ IU/ $\mathrm{ml}$ ) or sterile water for injection immediately before using in test.

\section{Results}

In $1997-2000,15$ samples were tested on bacterial endotoxins to verify the method in our laboratory conditions. Veterinary medicinal products intended for intramuscular and/or intravenous administrations in cats and dogs were analysed (Table 1).

Table 1

Products are stated under ATC code

\begin{tabular}{|c|c|c|c|}
\hline ATCvet code & $\begin{array}{c}\text { ATC Name } \\
\text { (Nordic Group) }\end{array}$ & Figure of sample & $\begin{array}{c}\text { Dilution of ananlyzed } \\
\text { sample }\end{array}$ \\
\hline QA11A & Vitamins & 1 & $1: 16$ \\
\hline QC03 BA & Cardiac therapy & 2 & $1: 50$ \\
\hline Q04 IA & Antiphlogistics & 1 & Undiluted, $1: 4$ \\
\hline Q07 AC QJ01C & Beta-lactamase sensitive penicilins & 1 & $1: 40$ \\
\hline QJ01A A & Tetracyclines & 1 & $1: 30$ \\
\hline QN02 & Nervous system therapy & 3 & $1: 64,1: 32$ \\
\hline QN05CM & Hypnotics and sedatives & 3 & $1: 32,1: 64$ \\
\hline QP52AD & Anthelmintics & 1 & $1: 16$ \\
\hline Q20 AA & Various & 1 & Undiluted \\
\hline Q020 AB & Homeopathics & 1 & 1 \\
\hline
\end{tabular}

The control standard endotoxin was used in concentrations of $0.5 ; 0.25 ; 0.125 ; 0.0625$ and $0.03125 \mathrm{EU} / \mathrm{ml}$. A negative control solution and a positive one formed always a part of a test.

In 6 products, the presence of pyrogens was examined using simultaneously the LAL test and the rabbit pyrogen test. Two products (Q04IA) passed the pyrogen test, by two others the test had to be repeated and they passed it on a group of three rabbits. Testing the products from ATC group Q09AA, two animals died during application and the test could not be carried out.

\section{Discussion}

Endotoxins contained in GNB are the most usual cause for toxic activities, which are induced by contamination of the drug products by pyrogenic substances. The pyrogenic activity of the endotoxins is higher than that of other pyrogenic substances.

The detection of the absence of endotoxins is important in parenteral drugs and for the user protection as well. In last few years, the use of LAL tests in the supervision of the production process of drugs is increasing, where the LAL test is employed in the detection and reduction of the contamination caused by endotoxins. The LAL test is also used in the supervision of final products in favor of the rabbit pyrogen test. The outcome of the test on pyrogenic substances carried on rabbits is dependent on the quantity of pyrogens in used dose.

The outcome of the test on bacterial endotoxins is proportional to the concentration of the 
endotoxins in the examined substance. LAL test could be carried on a smaller dose of examined material than the rabbit pyrogen test and is sensitive to a lover endotoxin levels than those needed to induce the pyrogenic reaction in rabbits.

The replacement of the rabbit pyrogen test by the LAL test is an alternative method and as such, it requires validation. This replacement is possible when the following conditions are met:

1. The endotoxin limit is defined for the material in consideration.

2. The set maximal endotoxin concentration level in such material is acceptable.

3. The standard test procedure and its validation are defined.

Substances, which induce an elevated body temperature in rabbits (their biological activities are similar to non-microbial pyrogens) are more efficiently supervised by the use of LAL test, focused on the presence of bacterial endotoxins. Of course, all the conditions for the validity of such test must be met.

\section{The Evaluation of the Rabbit Pyrogen Test}

The advantage of the rabbit pyrogen test is in the possibility of detection of other pyrogenic substances than endotoxins. This is important in the supervision of the new drugs, where the pyrogenic activities could be caused by used substances or vehiculum.

The disadvantage of the rabbit pyrogen test is in the first place the insufficient sensibility of rabbits on the detection of the presence of endotoxins, especially in i.v. products, water for infants and in low endotoxin concentration level products (ELC). The relative low accuracy of the reaction of elevation in body temperature results in the need for repetition of the test procedure on higher number of animals. Furthermore, the reactions of rabbits are influenced by the stress endured during handling and/or the current health condition. The rabbits need to be prepared for the testing, they must be accustomed to the new environment and handling procedures.

Another drawback is that large group of animals cannot be tested simultaneously (it takes 72 hours to carry on one test on three rabbits), at least two workers are required during this procedure for safety reasons.

The tests on animals are avoided either for ethical reasons and in accordance with " $3 \mathrm{R}$ rules" (refinement, reduction, replacement) (Russel and Burch 1992).

The Evaluation of LAL Test

Advantages of the LAL test:

- Small amount of the tested sample is required for the LAL test.

- Several samples could be tested daily.

- Only one trained worker is needed to carry on the tests.

- LAL test is more economical, despite higher initial expenses.

- A lower level of endotoxins could be detected than in rabbit pyrogen test.

- The testing method is highly standardised.

- Data for the final evaluation of the test could be obtained relatively quickly.

Disadvantages of the LAL test:

- High emphasis on the precise implementation of the test procedure.

- Slight disturbances could influence the outcome of the test.

\section{Conclusion}

Until recently, the only available means of pyrogenicity testing for parenteral drug products and medical devices was the rabbit pyrogen test. This test has a number of 
drawbacks, particularly cost. Thus it is readily apparent why the LAL test, originally developed by Levin and Bang, revolutionised the field of pyrogen testing. Compared with the rabbit pyrogen assay, the LAL test is more sensitive and accurate, is simple to perform, is cost effective, and requires no specialised equipment. Moreover, many parenteral products that are not amenable to rabbit pyrogen testing can be assayed for endotoxin using the LAL test, such as radiopharmaceuticals, hypnotics and even methotrexate. The LAL test, when meeting all validation demands, could fully replace the rabbit pyrogen test.

\section{LAL test - alternativní metoda detekce bakteriálních endotoxinů}

Limulus amebocyte lysate (LAL) test je alternativní metodou zkoušky na pyrogenní látky prováděné na králících, která je zaměřena na detekci pyrogenních látek ve sterilních parenterálních přípravcích.

Cílem práce je zhodnocení a zavedení metody pro stanovení bakteriálních endotoxinů (nejčastějších pyrogenů) LAL testem gelovou metodou do rutinního uživání. Bylo testováno celkem 15 vzorků na přítomnost bakteriálních endotoxinů $\mathrm{k}$ ověření této metody $\mathrm{v}$ našich laboratorních podmínkách. U šesti př́ípravků byla sledována přítomnost pyrogenů za současného použití LAL testu a testu na králících.

Nahrazení testu na králících LAL testem gelovou metodou je možné v případě, když je stanoven endotoxinový limit pro sledovaný přípravek, dostačuje stanovená limitní hladina koncentrace endotoxinů a je zaveden standardní operační postup včetně validace.

LAL test má mnoho výhod nad testem na králících, avšak jeden z nejvíce významných aspektů LAL testu je jeho soulad s nejnovějším požadavkem Evropské lékopisné komise na nahrazení testů na zviŕratech alternativními metodami tam, kde je to možné. Provedené zkoušky prokázaly, že LAL test může nahradit zkoušku na pyrogenní látky prováděnou na králících za předpokladu, že jsou splněny všechny validační parametry.

\section{References}

European Pharmacopoeia $3^{\text {rd }}$ Edition - Supplement 2001. Council of Europe, Strasbourg 2000, pp. $79-87$.

FRIBERG, P. 1987: The Use of Quantitative Assay in Endotoxin Testing. pp. 149-169, In: Watson, S (Ed.): Detection of Bacterial Endotoxins with the Limulus Amebocyte Lysate Test. Alan R. Liss, New York

LEVIN, J., BANG, F. B. 1964: The Role of Endotoxin in the Extracellular Coagulation of Limulus Blood. Bull. Johns Hopkins Hosp., p. 115

LEVIN, J., BANG, F. B. 1964: A Description of Cellular Coagulation in the Limulus. Bull. Johns Hopkins Hosp., p. 337

LEVIN, J., TOMASULO, P. A., OSER, R. S. 1970: Detection of Endotoxin in Human Blood and Demonstration of an Inhibitor. J. Lab. Clin. Med. 75:903.

RUSSEL, W. M. S., BURCH, R. L.: Principles of Humane Experimental Technique. London, Methuen 1992, $238 \mathrm{p}$.

YOUNG, N. S., LEVIN, J., PRENDERAGST, R. A. 1972: An Invertebrate Coagulation System Activated by Endotoxin: Evidence for Enzymatic Meditation M, J. Clin. Invest. 51:1790-1797; sec. rec. in BioWhittaker, Inc. 1993: Multi-test Limulus Amebocyte Lysate Pyrogentplus, Walkersville, 10 p. 